\title{
HARNESSING THE ANTIOXIDANT PROPERTY OF CERIUM AND YTTRIUM OXIDE NANOPARTICLES TO ENHANCE MESENCHYMAL STEM CELL PROLIFERATION
}

\author{
HADEER A AGLAN ${ }^{1,2}$, MOSTAFA MABROUK ${ }^{3}$, RIHAM M ALY ${ }^{2,4}$, HANAN H BEHEREI ${ }^{3}$, HANAA H AHMED ${ }^{1,2 *}$ \\ ${ }^{1}$ Hormones Department, National Research Centre, Giza, Egypt. ${ }^{2}$ Stem Cells Lab, Center of Excellence for Advanced Sciences, National \\ Research Centre, Giza, Egypt. ${ }^{3}$ Refractories, Ceramics and Building Materials Department, National Research Centre, Giza, Egypt. ${ }^{4}$ Basic \\ Dental Science Department, National Research Centre, Giza, Egypt. Email: hanaaomr@yahoo.com
}

Received: 23 January 2018, Revised and Accepted: 2 August 2018

ABSTRACT

Objective: This work was designed to explore if cerium oxide $\left(\mathrm{CeO}_{2}\right)$ and yttrium oxide $\left(\mathrm{Y}_{2} \mathrm{O}_{3}\right)$ nanoparticles as antioxidant agents could potentiate the proliferation of mesenchymal stem cells (MSCs) derived from human dental pulp (hDPSCs).

Methods: Nanoparticles were characterized by transmission electron microscopy, particle size and zeta potential, X-ray diffraction, Fourier-transform infrared spectroscopy, and scanning electron microscope (SEM) along with energy-dispersive X-ray spectrometry. Furthermore, MSCs were isolated from human dental pulp, propagated and characterized by flow cytometry. Thereafter, the proliferative impact of the suggested nanoparticles on hDPSCs was investigated by 3-(4,5)-dimethylthiazol)-2,5-diphenyl tetrazolium bromide assay.

Results: Different sizes (14.09-26.50 nm and 18.80-31.31 nm) for $\mathrm{CeO}_{2}$ and $\mathrm{Y}_{2} \mathrm{O}_{3}$ respectively, morphology, charges, and proliferative efficacy in hDPSCs were recorded for both nanoparticles.

Conclusion: Generally speaking, the tested nanoparticles heightened the proliferative response of hDPSCs with the most prominent effect exerted by $15 \mu \mathrm{g} / \mathrm{ml}$ of $\mathrm{CeO}_{2}$ and $5 \mu \mathrm{g} / \mathrm{ml}$ of $\mathrm{Y}_{2} \mathrm{O}_{3}$. It is reasonable to assume that the antioxidant property of $\mathrm{CeO}_{2}$ and $\mathrm{Y}_{2} \mathrm{O}_{3}$ be involved in strengthening the proliferation process of hDPSCs.

Keywords: Mesenchymal stem cells, Cerium oxide nanoparticles, Yttrium oxide nanoparticles, Antioxidant effect, Proliferative impact.

(C) 2018 The Authors. Published by Innovare Academic Sciences Pvt Ltd. This is an open access article under the CC BY license (http://creativecommons. org/licenses/by/4. 0/) DOI: http://dx.doi.org/10.22159/ajpcr.2018.v11i9.27914

\section{INTRODUCTION}

The particular target of tissue engineering is to promote the repairment of the destroyed tissue and maintain its functional features [1]. Clinical usage of dental stem cells as biological progenitor candidates for tissue regeneration was recently reported [2]. However, there are many factors hinder the clinical application of mesenchymal stem cells (MSCs) such as culturing obstacles, high transformation risk, and down proliferation rate in vitro [3]. Furthermore, many studies showed some drawbacks, because of lower viability of the transplanted cells. Particularly, about $99 \%$ of implanted cells died at the $1^{\text {st }} \mathrm{h}$ after the implantation process and this could be owed to the harshness of the human biological environment that the cells face on implantation $[4,5]$. One of the major causative factors for implanted cell death is oxygen deficiency due to delayed revascularization at the site of implantation [6].

Intracellular oxidative stress may be developed during the isolation of cells, multiple handling, and preparation steps of the sample as well as addition of proteolytic enzymes at reseeding stage. Earlier reports have mentioned that the increase in the intracellular reactive oxygen species (ROS) levels in the lag phase of cell growth is capable of suppressing the rate of proliferation [7]. Therefore, different approaches were intended to oppose the biological microenvironmental stress facing the cells before the transplantation procedures. Among these developed strategies is the in vitro introduction of nanoparticles rare earth oxides into MSCs cultures in order to be utilized as free radical quenchers within these cells [8].

Cerium oxide $\left(\mathrm{CeO}_{2}\right)$ nanoparticles, also known as nanoceria, have a great potential to scavenge superoxide anions, hydrogen peroxide, and peroxynitrite in vivo [9]. Depending on the surface oxidation state, $+3 /+4$, nanoceria could mimic the activity of the cellular antioxidant enzymes, superoxide dismutase and catalase $[10,11]$. Aside from these properties, $\mathrm{CeO}_{2}$ nanoparticles could augment angiogenesis through adjusting the intracellular oxygen environment and stabilizing hypoxia inducing factor $1 \alpha$ endogenously [12].

Yttrium oxide $\left(\mathrm{Y}_{2} \mathrm{O}_{3}\right)$, a vastly utilized host material for various rare earth dopants, is of interest for its potency to be applied in biological imaging and photodynamic therapy [13]. $\mathrm{Y}_{2} \mathrm{O}_{3}$ has been shown to protect rat pancreatic islets from oxidative stress-mediated apoptosis [14]. $\mathrm{Y}_{2} \mathrm{O}_{3}$ nanoparticles are well known as excellent free radical scavengers due to their non-stoichiometric crystal defects [15].

Although the therapeutic influence of $\mathrm{CeO}_{2}$ and $\mathrm{Y}_{2} \mathrm{O}_{3}$ nanoparticles was previously studied with different cell lines, their antioxidant and proliferative effects on the human dental pulp-derived mesenchymal stem cells (hDPSCs) in vitro have not been reported yet. The above motivations were investigated in a comparative manner between $\mathrm{CeO}_{2}$ and $\mathrm{Y}_{2} \mathrm{O}_{3}$ nanoparticles. It is relevant to note that different techniques such as transmission electron microscopy (TEM), particle size and zeta potential, X-ray diffraction (XRD), Fourier-transform infrared (FTIR), and scanning electron microscope (SEM) coupled with energy-dispersive $\mathrm{X}$-ray spectrometry (EDX) were applied for the studied nanoparticles to demonstrate their size, morphology, potential charges, physicochemical characters, and elemental properties before conducting the in vitro assay.

\section{METHODS}

Nanoparticles

Cerium (IV) oxide $\left(\mathrm{CeO}_{2}\right)$ and yttrium (III) oxide $\left(\mathrm{Y}_{2} \mathrm{O}_{3}\right)$ nanoparticles were purchased from Sigma-Aldrich (St Louis, Missouri, USA).

Size and morphology of the nanoparticles: Transmission electron microscopy (TEM)

TEM was used to analyze the crystal structure, size, and morphology of the investigated nanoparticles. Practically, TEM images were recorded 
for $\mathrm{CeO}_{2}$ and $\mathrm{Y}_{2} \mathrm{O}_{3}$ nanoparticles using TEM, JEOL JEM-2100 with an accelerating voltage of $200 \mathrm{kV}$.

\section{Size distribution and zeta potential: Dynamic light scattering} (DLS) zetasizer

Electrophoretic measurements were obtained using a Zetasizer Nano ZS (Malvern Instruments, UK) equipped with a 633-nm laser. The reference standard (DTS1230, zeta-potential standard from Malvern) was used to qualify the performance of the instrument. Samples $(50 \mathrm{mg}$ ) were suspended in $10 \mathrm{ml}$ of deionized water and were filtered using a $0.22-\mu \mathrm{m}$ filter before analysis. Sample preparation involved filling of a disposable capillary cell (DTS1060, Malvern). Before their use, these cells were thoroughly cleaned with ethanol and deionized water, as recommended by the instrument vendor. For analysis, the individual cell was filled with the appropriate sample and flushed before refilling; measurement was carried out on the second filling. Malvern Instrument's Dispersion Technology software (Version 4.0) was used for data analysis, and zeta-potential values were estimated from the measured electrophoretic mobility data using the Smoluchowski equation.

\section{Physicochemical characterizations: XRD}

XRD patterns of $\mathrm{CeO}_{2}$ and $\mathrm{Y}_{2} \mathrm{O}_{3}$ nanoparticles were measured by using Rigaku X-ray diffractometer. The monochromatic X-rays with a wavelength of $0.1542 \mathrm{~nm}$ were generated using a $\mathrm{Cu} K \alpha$ source with an emission current of $200 \mathrm{~mA}$ and a voltage of $40 \mathrm{kV}$. Samples scans were measured from 5 to $60^{\circ}$ at a scan speed of $4^{\circ} / \mathrm{min}$.

\section{Physicochemical characterizations: FTIR analysis}

FTIR analysis was used to investigate the functional groups of the $\mathrm{CeO}_{2}$ and $\mathrm{Y}_{2} \mathrm{O}_{3}$ nanoparticles. Before analysis, $2 \mathrm{mg}$ of nanopowders were mixed with $200 \mathrm{mg} \mathrm{KBr}$ in the mortar and grinded into a fine powder then pressed into solid disks of $0.5 \mathrm{~cm}$ diameter. FTIR spectra were recorded using a Perkin Elmer Spectrum 2000 FTIR spectrometer, employing a single-reflection diamond MIRTGS detector (PerkinElmer Spectrum 100, Llantrisant, Wales, UK). All samples were analyzed by a universal FTIR spectrum series at a resolution of $4 \mathrm{~cm}^{-1}$.

\section{Microstructure and elemental composition: SEM-EDX analysis}

The morphology and the elemental analysis of $\mathrm{CeO}_{2}$ and $\mathrm{Y}_{2} \mathrm{O}_{3}$ nanoparticles were conducted using SEM with EDX. SEM images were recorded using a JEOL JXA-840A, Electronprobe microanalyzer, Japan, at $15 \mathrm{kv}$. Samples were rendered electrically conductive before analysis through gold-sputter coating (SPI Module ${ }^{\mathrm{TM}}$ Sputter Coater, SPI Supplies, PA) and were attached to the SEM stub using adhesive carbon tape.

\section{Derivation and maintenance of hDPSCs}

This study was approved by the Ethical Committee of the Medical Research of the National Research Centre, Egypt (Approval no.16386). hDPSCs were isolated from human dental pulp of adult subjects undergoing routine tooth extraction according to Gronthos et al. [16] protocol. The collected tissue was digested in solution of $0.2 \%$ Collagenase type II (Serva Electrophoresis GmbH). The isolated dental pulp cells cultured in fresh Dulbecco's modified Eagle's medium (DMEM, Lonza, Belgium) supplemented with $10 \%$ fetal bovine serum (FBS, Lonza) were incubated at $37^{\circ} \mathrm{C}$ and $5 \% \mathrm{Co}_{2}$. Medium was changed twice per week thereafter. Once the cells became $80 \%-90 \%$ confluent, they were passaged. On the time of passaging, the cells in each culture dish were treated with $0.5 \%$ trypsin/EDTA (Lonza).

\section{Cell surface antigen analysis}

After the third passage, hDPSCs were released by trypsinization. The cells were incubated with FITC-conjugated CD 34 (Dako Co., Denmark) or PE-conjugated CD 90 (R and D Systems, UK) antibodies for $30 \mathrm{~min}$ at $4^{\circ} \mathrm{C}$ and PE-conjugated CD 105 (Miltenyi Biotec, Germany) antibody for $10 \mathrm{~min}$ at $4^{\circ} \mathrm{C}$ followed by flow cytometric analysis using Beckman Coulter Elite XL, USA instrument.

\section{Proliferative assay}

hDPSCs proliferation was determined using 3-[4,5-dimethylthiazol2-yl]-2,5 diphenyl tetrazolium bromide (MTT, Sigma, USA) assay according to the method of van Meerloo et al. [17]. Briefly, hDPSCs were seeded in 96-well plates at the density of $1 \times 10^{4}$ cells/well and cultured for $12 \mathrm{~h}$ under $5 \% \mathrm{Co}_{2}$ and $37^{\circ} \mathrm{C}$. Thereafter, each one of the suggested nanoparticles at various concentrations $(2,5,10,15,20$, and $25 \mu \mathrm{g} / \mathrm{ml}$ ) was added per well. Media without drug were added as control. After 24, 48, and $72 \mathrm{~h}$ incubations, MTT dissolved in PBS was added to each well at a final concentration of $5 \mathrm{mg} / \mathrm{ml}$, and the samples were incubated at $37^{\circ} \mathrm{C}$ for $4 \mathrm{~h}$. Water-insoluble crystals of formazan that formed during MTT cleavage in actively metabolizing cells were then dissolved in dimethyl sulfoxide. Absorbance was measured at $450 \mathrm{~nm}$, using a microplate reader (Model 500; BIO-RAD Instrument Inc., USA). The cells proliferation (\%) was calculated and compared with the control.

\section{Statistical analyses}

All experiments were carried out at least in triplicate, and data were expressed as mean \pm standard deviation.

\section{RESULTS AND DISCUSSION}

\section{Size and morphology of the nanoparticles}

The transmission electron microscopic analysis was conducted to assert the actual size, morphology of the nanoparticles, their growth pattern, and the distribution of the crystallites. TEM analysis of $\mathrm{CeO}_{2}$ nanoparticles showed uniform nanostructures of nanocubes with an average diameter of $18.80-31.31 \mathrm{~nm}$ and length of $84.17 \mathrm{~nm}$ (Fig. 1a). The obtained result matches to the $\mathrm{CeO}_{2}$ nanoparticles early reported by Li et al. [18]. On the other side, the morphology of $\mathrm{Y}_{2} \mathrm{O}_{3}$ nanoparticles demonstrated a high homogeneity of semisphericalshaped nanoparticles with a diameter in the range of 14.09-26.50 nm (Fig. 1b). This result comes in the line with the previous study of Soga et al. [19].

\section{Size distribution and zeta potential of the nanoparticles}

Size distribution and zeta potential are vital and very advantageous factors in the investigation of the nanoparticle properties and cell materials interaction. Fig. 2a represents the particle size of $\mathrm{CeO}_{2}$ in the deionized water. An average particle size of $\mathrm{CeO}_{2}$ was $469.4 \mathrm{~nm}$ in $100 \%$ as obtained from the DLS measurement which is considered a little bit higher as compared to the particle size shown in the TEM image of $\mathrm{CeO}_{2}$. The higher particle size (obtained from DLS measurement) could be owed to the expected agglomerations and the dynamic scattering of the nanoparticles within the dispersion medium [20]. The zeta potential of $\mathrm{CeO}_{2}$ at the same conditions is illustrated in Fig. $2 \mathrm{~b}$ as it is expressed by two peaks +2.53 and $-137 \mathrm{mV}$ with the area $\%$ values 77 and $23 \%$, respectively.

The size distribution of $\mathrm{Y}_{2} \mathrm{O}_{3}$ nanoparticles is measured at the abovementioned conditions and depicted in Fig. 2c. It is noted that the $\mathrm{Y}_{2} \mathrm{O}_{3}$ nanoparticles exhibited a smaller average particle size of $46.1 \mathrm{~nm}$ in $100 \%$ compared to that observed for $\mathrm{CeO}_{2}$ nanoparticles as confirmed
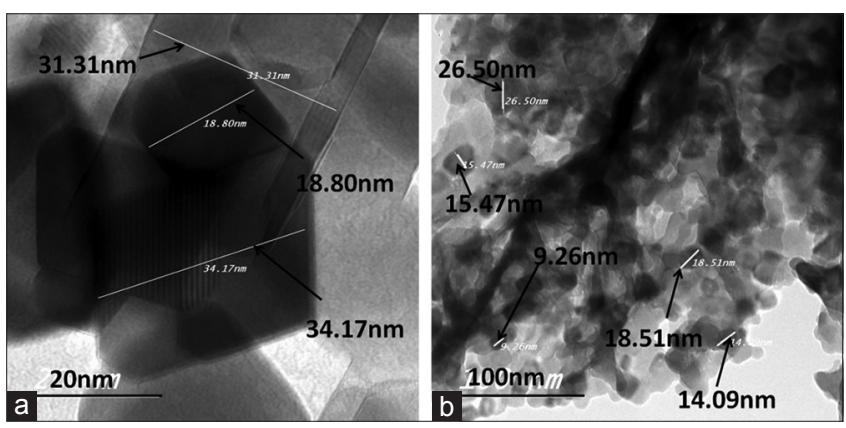

Fig. 1: Transmission electron microscopy images of (a) cerium oxide and (b) yttrium oxide nanoparticles 
by the DLS measurement. This result is consistent with the TEM finding although, the obvious size difference between the two measurements owing to their different operating techniques. The zeta potential of $\mathrm{Y}_{2} \mathrm{O}_{3}$ shown in Fig. 2d exhibited only one peak of $\mathrm{Y}_{2} \mathrm{O}_{3}$ obtained at $-0.442 \mathrm{mV}$ with the area percentage value of $100 \%$.

XRD analysis of the nanoparticles

To speculate the physical phases and phase purity of the nanoparticles under investigation, XRD analysis was conducted. $\mathrm{CeO}_{2}$ nanoparticles elicited characteristic peaks, which are very close to the cubic phase of structured $\mathrm{CeO}_{2}$ crystal (Fig. 3a). The characteristic peaks corresponding to the (111), (200), (220), (311), (222), (400), (331), (420), and (422) planes are located at $2 \theta=29.2^{\circ}, 33.1^{\circ}, 47.5^{\circ}, 57.6^{\circ}$, $59.0^{\circ}, 64.5^{\circ}, 76.7^{\circ}, 79.2^{\circ}$, and $88.4^{\circ}$, respectively. This result fits the recently reported finding of Farahmandjou et al. [21]. Moreover, no peaks of any other phase were registered indicating the high purity of the $\mathrm{CeO}_{2}$ nanoparticles. In addition, the sharp diffraction peaks that are observed for the $\mathrm{CeO}_{2}$ nanoparticles emphasize the small sizes of $\mathrm{CeO}_{2}$ crystallites as well as a homogeneous arrangement. These data echo those previously cited by Atta et al. [22].

The physical phase of the $\mathrm{Y}_{2} \mathrm{O}_{3}$ nanoparticles was inspected by the XRD analysis, and the spectrum is shown in Fig. 3b. The obtained peaks are corresponded, respectively, to the (222), (400), (411), (332), (431), (440), (611), and (622) planes of main crystalline $\mathrm{Y}_{2} \mathrm{O}_{3}$ nanoparticles phase. These results are consistent with the Joint Committee on Powder Diffraction Standards, card No. 41-1105. The room temperature lattice parameter of the unit cell of the yttria phase estimated by the XRD pattern is matched with the JCPDS database of number 83-0927. Weak peaks for $\mathrm{MgO}$ at $2 \theta=37.1,43.4$, and $62.5^{\circ}$ are also detected (Fig. $3 \mathrm{~b}$ ).

FTIR spectra of the nanoparticles

FTIR measurements were conducted for the subjected nanoparticles to elucidate the chemical integrity of the particles, and the spectra are represented in Fig. 4. The $\mathrm{CeO}_{2}$ nanoparticle FTIR spectrum is shown in Fig. $4 \mathrm{a}$, in the range of $400-4000 \mathrm{~cm}^{-1}$ wave numbers. In details, the large broad band is observed at $3415 \mathrm{~cm}^{-1}$ which is ascribed to the $\mathrm{O}-\mathrm{H}$ stretching vibration in $\mathrm{OH}^{-}$groups. Absorption band is noted around $1464 \mathrm{~cm}^{-1}$ which is assigned to the bending vibration of $\mathrm{CO}_{2}$ stretching. The intense band at $500 \mathrm{~cm}^{-1}$ corresponds to the Ce-O stretching vibration. The bands located at 741, 750, and $1036 \mathrm{~cm}^{-1}$ have been attributed to the $\mathrm{CO}_{2}$ asymmetric stretching vibration, $\mathrm{CO}_{3}^{-2}$ bending vibration, and $\mathrm{C}-\mathrm{O}$ stretching vibration, respectively. The bands located at $1298 \mathrm{~cm}^{-1}$ are attributed to carbonate species vibrations [23].

The FTIR spectrum for $\mathrm{Y}_{2} \mathrm{O}_{3}$ is illustrated in Fig. 4b. Absorption bands are observed around 500 and $600 \mathrm{~cm}^{-1}$, corresponding to oxygen metal as reported for $\mathrm{Y}_{2} \mathrm{O}_{3}$ by Jeong and Bae [24]. The bands noted around 1640 and $1555 \mathrm{~cm}^{-1}$ correspond to asymmetric stretching of $\mathrm{C}-\mathrm{O}$ band which may arise from the absorption of $\mathrm{CO}_{2}$ from the atmosphere.

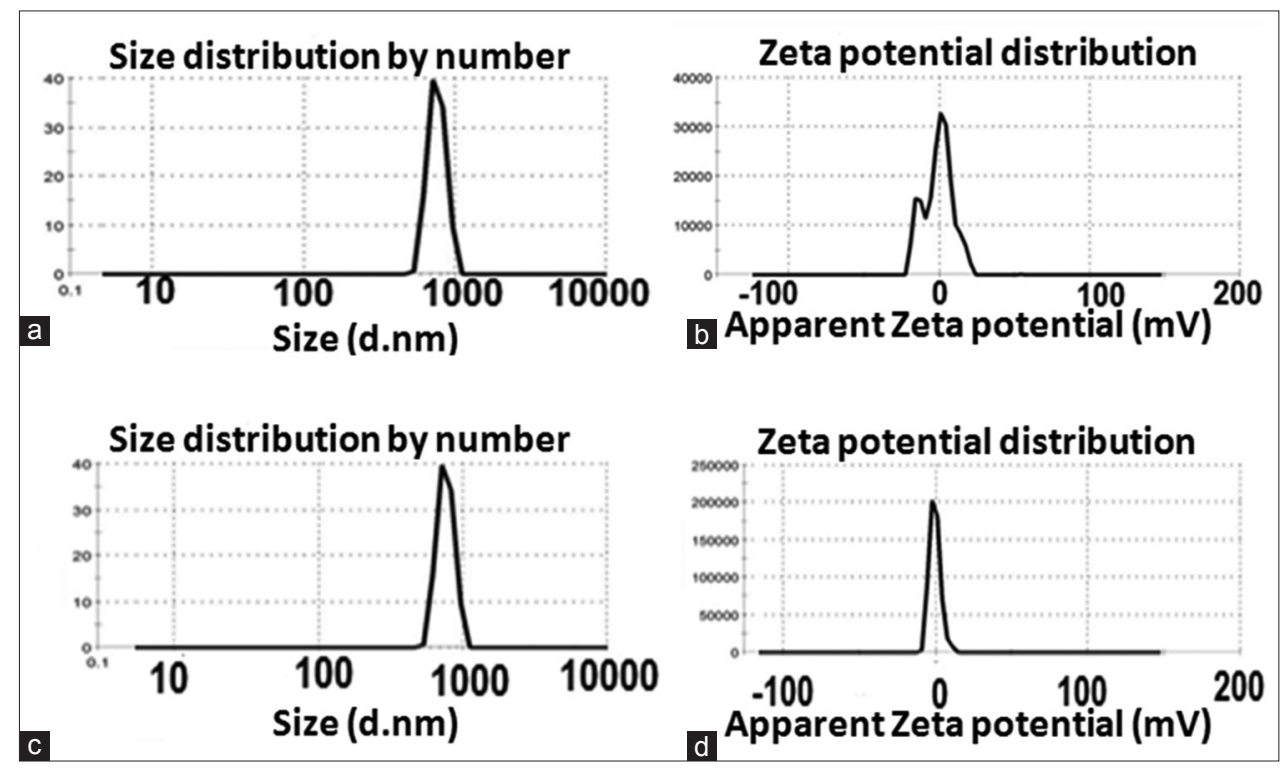

Fig. 2: Illustrates of (a) size distribution, (b) zeta potentials of cerium oxide nanoparticles, (c) size distribution, and (d) zeta potentials of yttrium oxide nanoparticles

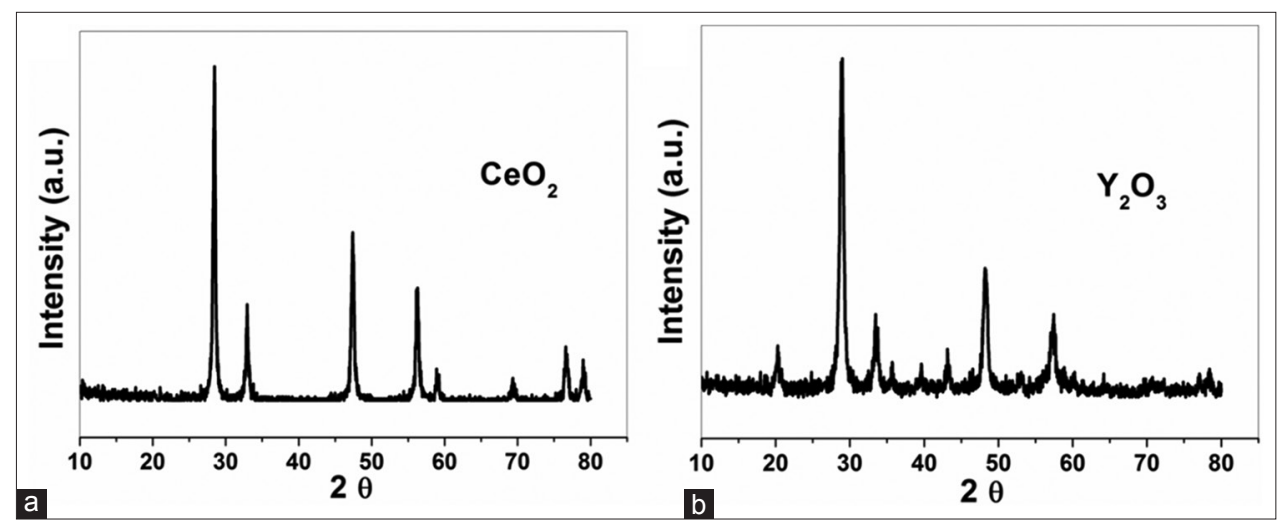

Fig. 3: X-ray diffraction of (a) cerium oxide and (b) yttrium oxide nanoparticles 
The bands observed in the region of $3647.14-3403.46 \mathrm{~cm}^{-1}$ and $1508.23 \mathrm{~cm}^{-1}$ may be due to the presence of $\mathrm{OH}$ stretching and bending vibration modes, respectively. This phenomenon may be resulting from both hydroxyl groups and strongly adsorbed molecular water in the crystal lattice of yttrium hydroxide [24]. This is obviously noted in the frequency region of $3470-3200 \mathrm{~cm}^{-1}$ for both oxides which may be attributed to vibrational mode of $\mathrm{OH}$, resulting from the presence of moisture in $\mathrm{KBr}$ disc. The bands observed at $526.53-694.33 \mathrm{~cm}^{-1}$ are assigned to the stretching vibration of $\mathrm{Y}-\mathrm{O}$ bonds as mentioned in the previous study of Schwartz and Schwartz [25].

\section{SEM measurements and elemental analysis of the nanoparticles} Undoubtedly, the purity and the morphology of the nanoparticles are very critical factors in studying the cells-nanomaterials interactions. Therefore, SEM measurements and elemental analysis of the two nanoparticles are conducted and showed in Fig. 5. In general, both nanoparticles exhibited similar morphology of fused and aggregated nanoparticles. The EDX of $\mathrm{CeO}_{2}$ nanoparticles is shown in Fig. 5a which confirmed its purity as only $\mathrm{Ce}$ and $\mathrm{O}$ elements are detected. The presence of very minor impurity ( $\mathrm{C}$ and $\mathrm{F}$ ) in $\mathrm{Ceo}_{2}$ is also noted which may be adsorbed from the atmosphere or due to the sample handling. The EDX of $\mathrm{Y}_{2} \mathrm{O}_{3}$ as shown in Fig. $5 \mathrm{~b}$ documented its purity as only $\mathrm{Y}$ and 0 elements are detected. The presence of very minor impurity ( $\mathrm{C}$ and $\mathrm{Al}$ ) in $\mathrm{Y}_{2} \mathrm{O}_{3}$ is also observed which may be adsorbed from the atmosphere or due to the sample handling.

\section{MSC surface markers}

Flow cytometric analysis revealed that hDPSCs are positive for CD90 (98.5\%) and CD105 (99.5\%) and negative for CD34 (0.81\%) as represented in Fig. 6. Similar results were previously reported for hDPSCs obtained from various cryopreservation methods of human dental pulp tissues of diseased teeth [26]

\section{Effect of nanomaterials on MSC proliferation}

Cell viability was quantitatively estimated employing colorimetric MTT assay that detects the mitochondrial activity of the cells. The MTT assay is based on the reduction of the yellow tetrazolium dye MTT to a purple water-insoluble formazan in cells bearing intact mitochondria and hence reflects the state of cultured cells. MTT assay results showed that the percentage viability of hDPSCs treated with $\mathrm{CeO}_{2}$ nanoparticles at concentrations of 15,20 , and $25 \mu \mathrm{g} / \mathrm{ml}$ for $24 \mathrm{~h}$ are about 134.3, 124.4 , and $117 \%$, respectively (Fig. $7 \mathrm{a}$ ), compared to the negative control (cells alone), while the percentage viability of hDPSCs treated with $\mathrm{CeO}_{2}$ nanoparticles at concentrations of 15,20 , and $25 \mu \mathrm{g} / \mathrm{ml}$ for

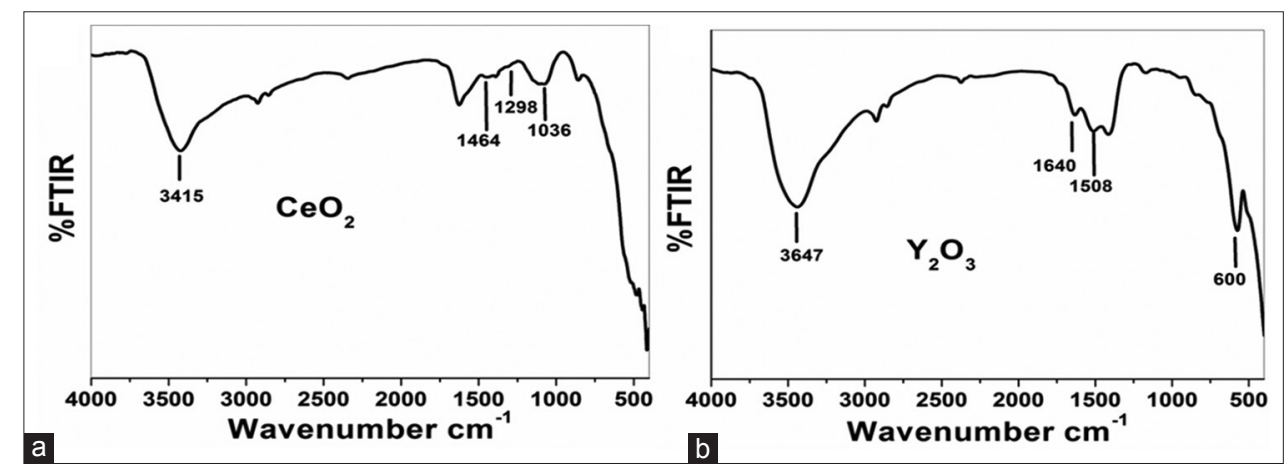

Fig. 4: Fourier-transform infrared spectroscopy of (a) cerium oxide and (b) yttrium oxide nanoparticles
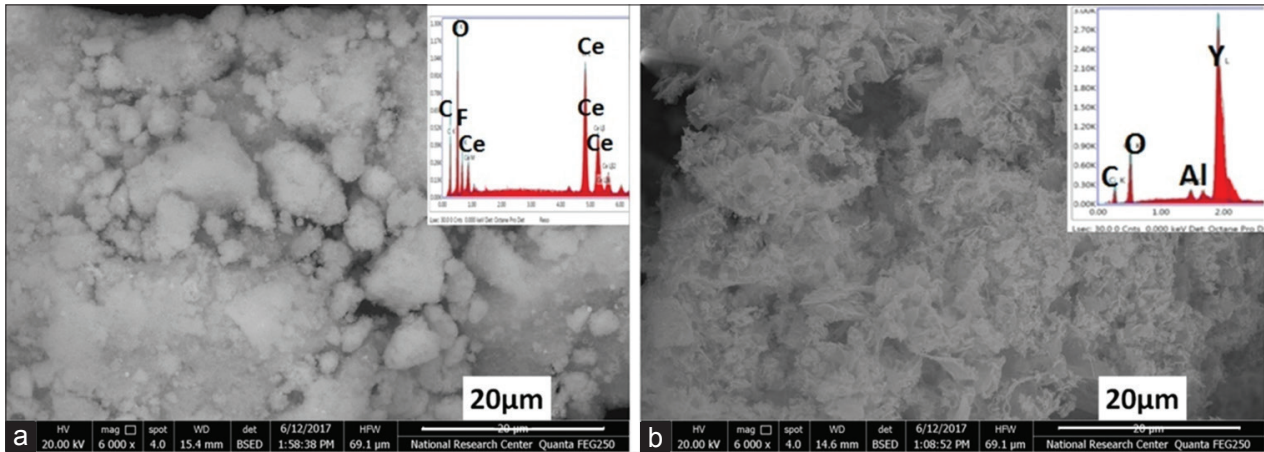

Fig. 5: Scanning electron microscope images and energy-dispersive X-ray spectrometry of (a) cerium oxide and (b) yttrium oxide nanoparticles
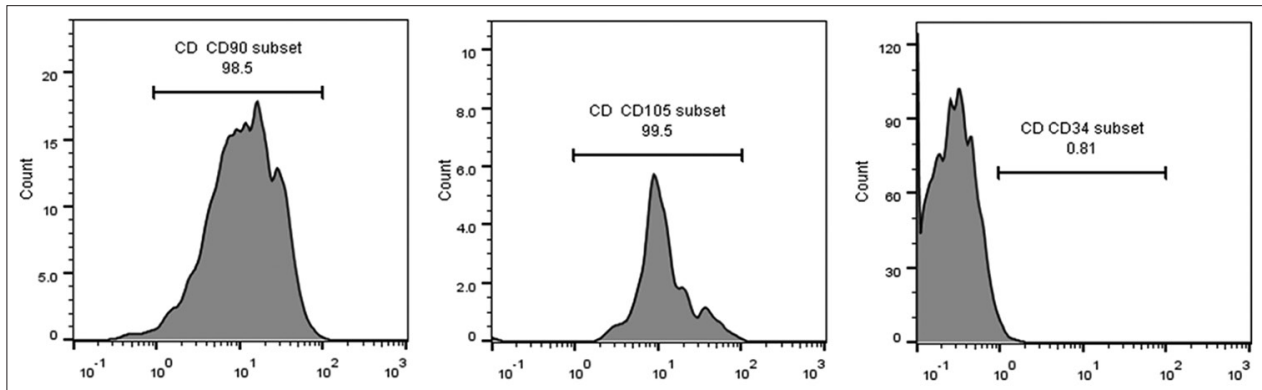

Fig. 6: Flow cytometric analysis of human dental pulp stem cells after staining with CD34, CD90, and CD105 antibodies 

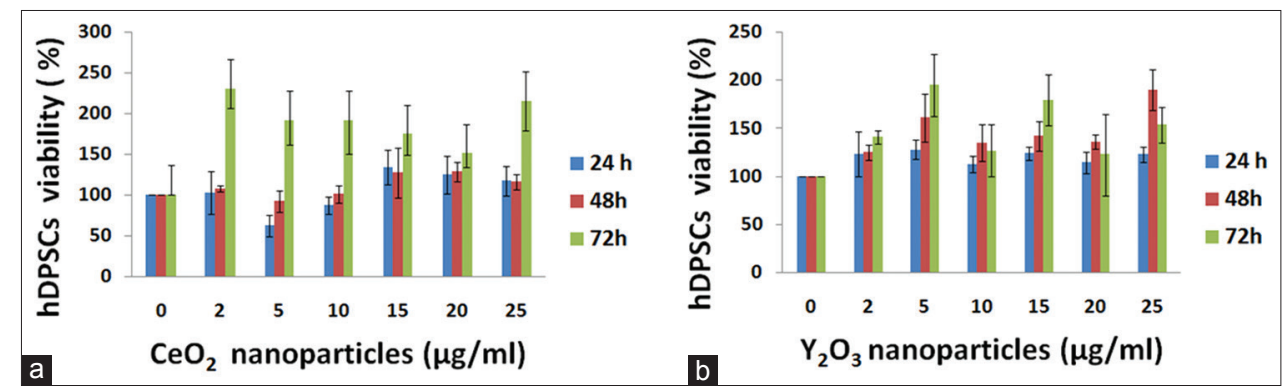

Fig. 7: Proliferation and viability of human dental pulp stem cells in the presence of different concentrations of (a) cerium oxide and (b) yttrium oxide nanoparticles for 24,48 , and $72 \mathrm{~h}$ (results are mean \pm standard deviation of the triplicate experiments)

$48 \mathrm{~h}$ are about $127.2,128.4$, and $116 \%$, respectively (Fig. $7 \mathrm{a}$ ), compared to the negative control. After $72 \mathrm{~h}$, treatment of hDPSCs with 2 and $25 \mathrm{\mu g} / \mathrm{ml}$ of $\mathrm{CeO}_{2}$ nanoparticles experienced marked positive impact on their percentage viability (229.7 for $2 \mu \mathrm{g} / \mathrm{ml}$ and $215.1 \%$ for $25 \mu \mathrm{g} / \mathrm{ml}$ of $\mathrm{CeO}_{2}$ nanoparticles) compared to the negative control (Fig. 7a). At the same time, the percentage viability of hDPSCs treated with $\mathrm{CeO}_{2}$ nanoparticles at concentrations of 5,10,15, and $20 \mu \mathrm{g} / \mathrm{ml}$ for $72 \mathrm{~h}$ are about 190.9, 191.8, 174.4, and 150.7\%, respectively (Fig. 7a), compared to the negative control.

The percentage viability of hDPSCs treated with $\mathrm{Y}_{2} \mathrm{O}_{3}$ nanoparticles at concentrations of $2,5,15$, and $25 \mu \mathrm{g} / \mathrm{ml}$ for $24 \mathrm{~h}$ are about 123.3, $127.6,124$, and $123 \%$, respectively, compared to the negative control (Fig. 7b). After $48 \mathrm{~h}$, treatment of hDPSCs with $\mathrm{Y}_{2} \mathrm{O}_{3}$ nanoparticles at a concentration of $25 \mu \mathrm{g} / \mathrm{ml}$ evoked marked positive effect on cell percentage viability (190.1\%) compared to the negative control (Fig. 7b). The percentage viability of hDPSCs treated with $\mathrm{Y}_{2} \mathrm{O}_{3}$ nanoparticles at concentrations of $2,5,10,15$, and $20 \mu \mathrm{g} / \mathrm{ml}$ for $48 \mathrm{~h}$ are about $124.7,160.5,134.6,142$, and $135.8 \%$, respectively, compared to the negative control (Fig. 7b). The percentage viability of hDPSCs treated with $\mathrm{Y}_{2} \mathrm{O}_{3}$ nanoparticles at concentration of $5 \mu \mathrm{g} / \mathrm{ml}$ for $72 \mathrm{~h}$ is about $194.5 \%$ compared to the negative control (Fig. 7b). Furthermore, after $72 \mathrm{~h}$, the percentage viability of hDPSCs treated with $\mathrm{Y}_{2} \mathrm{O}_{3}$ nanoparticles at concentrations of $2,10,15,20$, and $25 \mu \mathrm{g} / \mathrm{ml}$ are about $140.6,126.5,179.5,122.4$, and $153.4 \%$, respectively, compared to the negative control (Fig. 7b).

The remediation of biomedical materials, especially nanomaterials to MSCs, was found to be a promising tactic to modulate the cell functions particularly cell proliferation and differentiation into particular progenies [27-29]. Alteration of the antioxidant activity plays a key role in maintaining the optimum intracellular redox balance which is important for conserving the normal functioning of cellular systems, including DNA repair and stem cells signaling [30]. For stem cells, the intracellular redox balance is very critical, as the intracellular ROS level and genomic stability are related closely [31] and their imbalance resulted in spontaneous differentiation [32], loss of stemness [33], or transformation [34].

Based on our data, the chosen nanoparticles confer relatively different proliferative effect on hDPSCs. These findings go hand in hand with the previous reports carried out by Zhang et al. [35] who cited that $\mathrm{CeO}_{2}$ nanoparticles enhance the viability of bone marrow-derived MSCs at all tested concentrations with evident dose dependence for 24 and $72 \mathrm{~h}$. Popov et al. [36] mentioned that the introduction of nanocrystalline $\mathrm{CeO}_{2}$ doped with gadolinium $\left(\mathrm{Ce}_{1-\mathrm{x}} \mathrm{Gd}_{\mathrm{x}} \mathrm{O}_{\mathrm{y}}\right)$ into dental MSC culture promotes the cells proliferation in a dose-dependent manner. Moreover, a study on normal human colon cells proved that $\mathrm{CeO}_{2}$ nanoparticles rescued cell viability and reduced ROS production after irradiation [37]. Furthermore, $\mathrm{CeO}_{2}$ nanoparticles were found to quench free radicals in murine insulinoma cells treated with hydroquinone and in cultured retinal neurons treated with $\mathrm{H}_{2} \mathrm{O}_{2}$ [38]. Normal lung fibroblasts were protected from radiation-induced cell death by $\mathrm{CeO}_{2}$ nanoparticles [39]. Likewise, Li et al. [40] mentioned that ternary biomaterial composed of nHA/PA66/yttria-stabilized tetragonal zirconia increases the proliferation of osteoblast precursor cell line (MC3T3-E1 cells). Ghaznavi et al. [41] reported that both $\mathrm{CeO}_{2}$ and $\mathrm{Y}_{2} \mathrm{O}_{3}$ nanoparticles enhanced the survival of undifferentiated rat pheochromocytoma cells exposed to high glucose-induced oxidative stress.

Both $\mathrm{CeO}_{2}$ and $\mathrm{Y}_{2} \mathrm{O}_{3}$ nanoparticles are known as free radicals scavengers [41]. Mandoli et al. [42] suggested that the ability of $\mathrm{CeO}_{2}$ nanoparticles to enhance the growth and promote the adhesion and proliferation of MSCs in a biodegradable polymer matrix could possibly ascribed to its antioxidant activity. Antioxidants are believed to decrease intracellular ROS levels [43], and intracellular ROS plays a key role in regulating cell adhesion and cell proliferation [44]. As the increased levels of intracellular ROS during the initial period of cell growth delay their transition from the resting stage and initiation of proliferation [7]. Furthermore, earlier studies documented that low levels of ROS can affect pluripotent stem cell proliferation through controlling various signaling pathways including mitogen-activated protein kinase, nuclear factor kappa-light-chain-enhancer of activated B cells, and Wnt axis $[45,46]$. Furthermore, Kim et al. [47] found that low levels of ROS potentiate the proliferation and migration of MSCs by regulating the extracellular signal-regulated kinase and Jun-1/2 pathways. It has been reported that $\mathrm{CeO}_{2}$ nanoparticles can accelerate the proliferation of primary mouse embryonic fibroblasts through attenuating the intracellular ROS levels during the lag phase of cell growth and modifying the expression level of the major antioxidant enzymes [48]. Sun et al. [49] demonstrated that antioxidant treatment augments the entry of MSCs into the S phase by repressing cyclin-dependent kinase (CDK) inhibitors and results in rapid cell proliferation. They speculated that antioxidants can alter the cell cycle progression of MSCs by downregulating CDK and CDK4 inhibitors and upregulating CDK2, CDK4, and cell division cycle protein 2 homolog expression.

From another point of view, Horie et al. [50] cited that $\mathrm{CeO}_{2}$ nanoparticles have the ability to adsorb $\mathrm{Ca}^{2+}$-ions from culture medium and, on entering the cell cytoplasm, activate calcium-dependent proteins and consequently affect intracellular signaling pathways and the overall cell metabolism.

It would be pertinent to mention that the nanomaterials experienced the optimal proliferative effect on hDPSCs in the current work are negatively charged as indicated from their zeta potential data. In fact, the nanoparticle infiltration within the hDPSCs is thought to be controlled by more than one parameter, including the particles size, morphology, and charge [51-53]. According to the TEM and DLS measurements, the $\mathrm{Y}_{2} \mathrm{O}_{3}$ nanoparticles recorded less particle size $(14.09-26.50 \mathrm{~nm})$ than the $\mathrm{CeO}_{2}$ nanoparticles $(18.80-31.31 \mathrm{~nm})$. On the other side, the cell proliferation results demonstrated lower cell viability for the $\mathrm{Y}_{2} \mathrm{O}_{3}$ nanoparticles compared to that of $\mathrm{CeO}_{2}$ nanoparticles. Furthermore, negative charge $(-137 \mathrm{mV})$ with higher value was recorded for $\mathrm{CeO}_{2}$ nanoparticles compared with positive charge with little tendency to negativity recorded for the $\mathrm{Y}_{2} \mathrm{O}_{3}$ nanoparticles $(0.442 \mathrm{mV})$ as evidenced by DLS measurements. All the results suggested that the selected nanoparticles-cells interactions are highly dependent on the nanoparticles charge. This emphasizes the impressive role of nanoparticles charges over the particle size (limited to the nanoscale). 


\section{CONCLUSION}

The morphology, size, and charge of the chosen rare earth oxide nanoparticles were successfully investigated in a comparatively manner using specified tools. The present scenario gave us a valuable insight in the interpretation of the nanoparticles/cells interaction to come out with an acceptable idea about their mechanism of action as antioxidant agents. The potentiality of the chosen nanoparticles in improving the proliferation rate of MSCs seems to be linked with their ability to quench free radicals and maintain the optimal intracellular redox balance.

\section{ACKNOWLEDGMENT}

This work was financially supported by the National Research Centre (Egypt) under Grant no: 11010134

\section{AUTHOR'S CONTRIBUTION}

Hadeer A. Aglan: Responsible for determining the proliferative effect of suggested nanoparticles on hDPSCs and writing and revising the manuscript. Mostafa Mabrouk: Responsible for physicochemical characterization of the chosen nanoparticles, interpretation of data, and writing and revising the manuscript; Riham M. Aly: Responsible for isolating and propagating hDPSCs and revising the manuscript; Hanan H. Beherei: Responsible for physicochemical characterization of the chosen nanoparticles, interpretation of data, and revising the manuscript; and Hanaa H. Ahmed: Responsible for study concept, interpretation of data, and writing and revising the manuscript.

\section{CONFLICTS OF INTEREST}

The authors declare that they have no conflicts of interest.

\section{REFERENCES}

1. Murray PE, Garcia-Godoy F, Hargreaves KM. Regenerative endodontics: A review of current status and a call for action. J Endod 2007;33:377-90

2. Chen FM, Gao LN, Tian BM, Zhang XY, Zhang YJ, Dong GY, et al. Treatment of periodontal intrabony defects using autologous periodontal ligament stem cells: A randomized clinical trial. Stem Cell Res Ther 2016;7:33.

3. Zhang F, Ren T, Wu J, Niu J. Small concentrations of TGF-? 1 promote proliferation of bone marrow-derived mesenchymal stem cells via activation of Wnt/?-Catenin pathway. Indian J Exp Biol 2015;53:508-13.

4. Copland IB, Galipeau J. Death and inflammation following somatic cell transplantation. Semin Immunopathol 2011;33:535-50.

5. Trounson A, McDonald C. Stem cell therapies in clinical trials: Progress and challenges. Cell Stem Cell 2015;17:11-22.

6. Rouwkema J, Koopman B, Blitterswijk C, Dhert W, Malda J. Supply of nutrients to cells in engineered tissues. Biotechnol Genet Eng Rev 2010;26:163-78.

7. Muller F, Lustgarten M, Jang Y, Richardson A, Van Remmen H. Trends in oxidative aging theories. Free Radic Biol Med 2007;43:477-503.

8. Guin R, Banu S, Kurian GA. Synthesis of copper oxide nanoparticles using Desmodium gangeticum aqueous root extract. Int J Pharm Pharm Sci 2015;7:60-5.

9. Arya A, Gangwar A, Singh SK, Roy M, Das M, Sethy NK, et al. Cerium oxide nanoparticles promote neurogenesis and abrogate hypoxiainduced memory impairment through AMPK-PKC-CBP signaling cascade. Int J Nanomed 2016;23:1159-73.

10. Heckert EG, Karakoti AS, Seal S, Self WT. The role of cerium redox state in the SOD mimetic activity of nanoceria. Biomaterials 2008;29:2705-9.

11. Pirmohamed T, Dowding JM, Singh S, Wasserman B, Heckert E, Karakoti AS, et al. Nanoceria exhibit redox state-dependent catalase mimetic activity. Chem Commun (Camb) 2010;46:2736-8.

12. Das S, Singh S, Dowding JM, Oommen S, Kumar A, Sayle TX, et al. The induction of angiogenesis by cerium oxide nanoparticles through the modulation of oxygen in intracellular environments. Biomaterials 2012;33:7746-55

13. Chang ML, Tie SL. Fabrication of novel luminor Y2O3: Eu3+@ SiO2 (a) YVO4: Eu3+ with core/shell hetero nanostructure. Nanotechnology 2008;19:75711.
14. Hosseini A, Baeeri M, Rahimifard M, Navaei-Nigjeh M, Mohammadirad A, Pourkhalili N, et al. Antiapoptotic effects of cerium oxide and yttrium oxide nanoparticles in isolated rat pancreatic islets. Hum Exp Toxicol 2013;32:544-53.

15. Mitra RN, Merwin MJ, Han Z, Conley SM, Al-Ubaidi MR, Naash MI. Yttrium oxide nanoparticles prevent photoreceptor death in a light-damage model of retinal degeneration. Free Radic Biol Med 2014;75:140-8.

16. Gronthos S, Brahim J, Li W, Fisher LW, Cherman N, Boyde A, et al. Stem cell properties of human dental pulp stem cells. J Dent Res 2002;81:531-5.

17. van Meerloo J, Kaspers GJ, Cloos J. Cell sensitivity assays: The MTT assay. Methods Mol Biol 2011;731:237-45.

18. Li J, Zhang Z, Gao W, Zhang S, Ma Y, Qu Y. Pressure regulations on the surface properties of $\mathrm{CeO}_{2}$ nanorods and their catalytic activity for $\mathrm{CO}$ oxidation and nitrile hydrolysis reactions. ACS Appl Mater Interfaces 2016;8:22988-96

19. Soga K, Okumura Y, Tsuji K, Venkatachalam N. Effect of K3PO4 addition as sintering inhibitor during calcination of $\mathrm{Y} 2 \mathrm{O} 3$ nanoparticle. J Phys 2009;191:1-7.

20. Mahapatra C, Singh RK, Lee JH, Jung J, Hyun JK, Kim HW. Nanoshape varied cerium oxide nanomaterials rescue human dental stem cells from oxidative insult through intracellular or extracellular actions. Acta Biomater 2017;50:142-53.

21. Farahmandjou M, Zarinkamar M, Firoozabadi TP. Synthesis of cerium oxide $(\mathrm{CeO} 2)$ nanoparticles using simple $\mathrm{CO}$-precipitation method. Rev Mex Fisic 2016;62:496-9.

22. Atta AH, El-Shenawy AI, Koura FA, Refat MS. Synthesis and characterization of some selenium nanometric compounds: Spectroscopic, biological and antioxidant assessments. World J Nano Sci Eng 2014;4:58-69.

23. Phoka S, Laokul P, Swatsitang E, Promarak V, Seraphin S, Maensiri S. Synthesis, structural and optical properties of $\mathrm{CeO} 2$ nanoparticles synthesized by a simple polyvinyl pyrrolidone (PVP) solution route. Mater Chem Phys 2009;115:423-8.

24. Jeong KJ, Bae DS. Synthesis and characterization of $\mathrm{Y} 2 \mathrm{O} 3$ powders by a modified solvothermal process. Korean J Mater Res 2012;22:78-81.

25. Schwartz CA, Schwartz J. Surface modification of Y2O3 nanoparticles. Langmuir 2007;23:9158-916.

26. Chen YK, Huang AH, Chan AW, Shieh TY, Lin LM. Human dental pulp stem cells derived from different cryopreservation methods of human dental pulp tissues of diseased teeth. J Oral Pathol Med 2011;40:793-800.

27. Lutolf MP, Gilbert PM, Blau HM. Designing materials to direct stemcell fate. Nature 2009;462:433-41.

28. Powar PV. Development status in the meadow of nanostructure magnetic drug delivery system and its promising applications. Int $\mathrm{J}$ Pharm Pharm Sci 2017;9:10-7.

29. Davison MJ, McMurray RJ, Smith CA, Dalby MJ, Meek RD. Nanopitinduced osteoprogenitor cell differentiation: The effect of nanopit depth. J Tissue Eng 2016;7:2041731416652778.

30. Valle-Prieto A, Conget PA. Human mesenchymal stem cells efficiently manage oxidative stress. Stem Cells Dev 2010;19:1885-93.

31. Li TS, Marb'an E. Physiological levels of reactive oxygen species are required to maintain genomic stability in stem cells. Stem Cells 2010:28:1178-85.

32. Higuchi M, Dusting GJ, Peshavariya H, Jiang F, Hsiao ST, Chan EC, et al. Differentiation of human adipose-derived stem cells into fat involves reactive oxygen species and forkhead box ol mediated upregulation of antioxidant enzymes. Stem Cells Dev 2013;22:878-88.

33. Perales-Clemente E, Folmes CD, Terzic A. Metabolic regulation of redox status in stem cells. Antioxid Redox Signal 2014;21:1648-59.

34. Mathieu J, Zhou W, Xing Y, Sperber H, Ferreccio A, Agoston Z, et al. Hypoxia-inducible factors have distinct and stage specific roles during reprogramming of human cells to pluripotency. Cell Stem Cell 2014;14:592-605.

35. Zhang Q, Ge K, Ren H, Zhang C, Zhang J. Effects of cerium oxide nanoparticles on the proliferation, osteogenic differentiation and adipogenic differentiation of primary mouse bone marrow stromal cells in vitro. J Nanosci Nanotechnol 2015;15:6444-51.

36. Popov AL, Tatarnikova OG, Popova NR, Selezneva II, Akkizov AY, Ermakov AM, et al. Ce1-xGdxOy nanoparticles stimulate proliferation of dental pulp stem cells in vitro. Nano Hybrids Composites 2017:13:26-31.

37. Colon J, Hsieh N, Ferguson A, Kupelian P, Seal S, Jenkins DW, et al. Cerium oxide nanoparticles protect gastrointestinal epithelium from radiation-induced damage by reduction of reactive oxygen 
species and upregulation of superoxide dismutase 2. Nanomedicine 2010;6:698-705.

38. Tsai YY, Oca-Cossio J, Agering K, Simpson NE, Atkinson MA, Wasserfall $\mathrm{CH}$, et al. Novel synthesis of cerium oxide nanoparticles for free radical scavenging. Nanomedicine (Lond) 2007;2:325.

39. Colon J, Herrera L, Smith J, Patil S, Komanski C, Kupelian P, et al. Protection from radiation-induced pneumonitis using cerium oxide nanoparticles. Nanomedicine 2009;5:225

40. Li Y, Li H, Zhang J, Zhao W, Shen J, Jiang D. In vitro evaluation of an yttria-stabilized zirconia reinforced nano-hydroxyapatite/polyamide 66 ternary biomaterial: Biomechanics, biocompatibility and bioactivity. RSC Adv 2016;6:114086-95.

41. Ghaznavi H, Najafi R, Mehrzadi S, Hosseini A, Tekyemaroof N, Shakeri-zadeh A, et al. Neuro-protective effects of cerium and yttrium oxide nanoparticles on high glucose-induced oxidative stress and apoptosis in undifferentiated PC12 cells. Neurol Res 2015;37:624-32.

42. Mandoli C, Pagliari F, Pagliari S, Forte G, Di Nardo P, Licoccia S, et al. Stem cell aligned growth induced by $\mathrm{CeO} 2$ nanoparticles in PLGA scaffolds with improved bioactivity for regenerative medicine. Adv Funct Mater 2010;20:1617

43. Kanda Y, Hinata T, Kang SW, Watanabe Y. Reactive oxygen species mediate adipocyte differentiation in mesenchymal stem cells. Life Sci 2011;89:250-8

44. Song H, Cha MJ, Song BW, Kim IK, Chang W, Lim S, et al. Reactive oxygen species inhibit adhesion of mesenchymal stem cells implanted into ischemic myocardium via interference of focal adhesion complex. Stem Cells 2010;28:555-63.

45. Jeong AY, Lee MY, Lee SH, Park JH, Han HJ. PPARdelta agonistmediated ROS stimulates mouse embryonic stem cell proliferation through cooperation of p38 MAPK and wnt/beta-catenin. Cell Cycle 2009;8:611-9.

46. Lee SH, Lee YJ, Han HJ. Effect of arachidonic acid on hypoxiainduced IL-6 production in mouse ES cells: Involvement of MAPKs, NF-kappaB, and HIF-1alpha. J Cell Physiol 2010;222:574-85.

47. Kim J, Song S, Park S, Song S, Xia Y, Sung J. Primary involvement of NADPH oxidase 4 in hypoxia induced generation of reactive oxygen species in adipose derived stem cells. Stem Cells Dev 2012;21:2212-21.

48. Popov AL, Popova NR, Selezneva II, Akkizov AY, Ivanov VK. Cerium oxide nanoparticles stimulate proliferation of primary mouse embryonic fibroblasts in vitro. Mat Sci Eng C 2016;68:406-13.

49. Sun LY, Pang CY, Li DK, Liao CH, Huang WC, Wu CC, et al. Antioxidants cause rapid expansion of human adipose-derived mesenchymal stem cells via $\mathrm{CDK}$ and $\mathrm{CDK}$ inhibitor regulation. J Biomed Sci 2013;20:53.

50. Horie M, Nishio K, Kato H, Fujita K, Endoh S, Nakamura A, et al. Cellular responses induced by cerium oxide nanoparticles: Induction of intracellular calcium level and oxidative stress on culture cells. J Biochem 2011;150:461-71.

51. Gratton SE, Ropp PA, Pohlhaus PD, Luft JC, Madden VJ, Napier ME, et al. The effect of particle design on cellular internalization pathways. Proc Natl Acad Sci U S A 2008;105:11613-8.

52. Agarwal R, Roy K. Intracellular delivery of polymeric nanocarriers: A matter of size, shape, charge, elasticity and surface composition. Ther Deliv 2013;4:705-23.

53. Agarwal R, Singh V, Jurney P, Shi L, Sreenivasan SV, Roy K. Mammalian cells preferentially internalize hydrogel nanodiscs over nanorods and use shape specific uptake mechanisms. Proc Natl Acad Sci U S A 2013;110:17247-52. 